\title{
Control of Rocky Mountain Iris and Vegetation Response on Mountain Meadows
}

\author{
RICHARD E. ECKERT, JR., ALLEN D. BRUNER, GERARD \\ J. KLOMP, AND FREDERICK F. PETERSON
}

Highlight: Application of 2, 3, or 4 lb/acre of 2,4-D in midJune or 3 or 4 lb/acre in early July gave 91 to $100 \%$ control of iris. Iris phenology at treatment ranged from late vegetative to late bloom. The $2 \mathrm{lb} /$ acre rate applied when seed capsules were forming controlled 73 to $85 \%$ and control was not uniform. Reduction in iris yield ranged from 398 to $1568 \mathrm{lb} /$ acre and averaged $925 \mathrm{lb} /$ acre. Iris control gave a significant increase in production of grass and grasslike species of from $274 \mathrm{lb} /$ acre $(58 \%)$ to $2364 \mathrm{lb} /$ acre (360\%) with an average of $1173 \mathrm{lb} /$ acre (180\%). Slender wheatgrass and Nevada bluegrass were the most responsive species. Yield of sage grouse food plants, dandelion and yarrow, was severely reduced the first year after all treatments. Total forb production was deficient or minimal for sage grouse, and dandelion was deficient. Total forb production and dandelion component appeared adequate for existing sage grouse populations in the second and subsequent years after treatment.

Mountain meadows occur adjacent to streams and seeps in mountainous topography in northern and central Nevada. Information on vegetative characteristics, importance for livestock and sage grouse (Centrocercus urophasianus), range condition, and improvement by seeding has been presented (Eckert et al., 1973). One range condition described was fair

The authors are range scientist, Plant Science Research Division, Agricultural Research Service, U.S. Department of Agriculture; junior range ecologist, Nevada Agricultural Experiment Station; range scientist, Plant Science Research Division, Agr. Res. Serv., U.S. Dep. Agr.; and associate professor of plant, soil, and water science, College of Agriculture, University of Nevada, Reno.

The work represents cooperative investigation from the Plant Science Research Division, Agr. Res. Serv., U.S. Dep. Agr. and the Agricultural Experiment Station, Univ, of Nevada, Reno (Journal Series Number 227).

The authors gratefully acknowledge the cooperation and financial support of the Bureau of Land Management, U.S. Department of the Interior, and the Nevada Department of Fish and Game.

Manuscript received J une $30,1972$. meadows with desirable species suppressed by Rocky Mountain iris (Iris missouriensis).

Iris is a common weed of native meadows and pastures in Nevada and adjacent states (Cords, 1960). Competition on good condition pastures and mowing on hay meadows restrict iris increase. However, the plant is a serious problem on poorly managed pastures and mountain meadows because it is unpalatable to livestock (Pryor and Talbert, 1958). Iris reproduces from seed and underground rootstocks. These rootstocks enable the plant to withstand heavy trampling and to spread rapidly when competitive vegetation is weakened (Dayton, 1960). Iris is well adapted to soils with the potential to support species of much greater forage value. Iris reduces the yield of palatable forage through competition and also limits utilization because livestock avoid forage in and around iris clumps.

Pryor and Talbert (1958), Cords (1960, 1972), and Robocker (1966) indicated the superiority of 2,4-D for iris control. Cords (1960), obtained over 90\% control with $4 \mathrm{lb} /$ acre of ester formulations of 2,4-D applied soon after bloom. However, none of these authors evaluated the effects of treatment on nontarget species.

Savage (1968), Savage et al. (1969), and Oakleaf (1971) showed the importance of meadows for sage grouse habitat and particularly the importance of meadow forbs as food plants during the summer. Therefore, we needed to find a rate of 2,4-D and application date to maximize iris control and minimize forb damage.

Objectives of this study were to 1) evaluate rates of 2,4-D and dates of application for iris control; 2) determine the response of livestock forage plants; and 3) determine the effect of treatment on sage grouse food plants, common dandelion (Taraxacum officinale) and western yarrow (Achillea lanulosa). 


\section{Experimental Areas and Procedures}

Studies were conducted at two locations from 1965 to 1971. Willow Creek is in central Nevada at $7400 \mathrm{ft}$ elevation. Precipitation averaged 17.0 inches with a range of 8.1 to 33.2 inches. Soil is a member of a fine-loamy, mixed, frigid family of Cumulic Haplaquolls. Long Meadow is in northcentral Nevada at $6600 \mathrm{ft}$ elevation. Precipitation averaged 20.1 inches with a range of 15.6 to 25.8 inches. Soil is a member of a fine-silty, mixed, frigid family of Typic Haplaquolls.

The best treatment suggested by Cords (1960) was evaluated at Long Meadow in 1965. Propylene glycol butyl ether ester of (2,4-dichlorophenoxy) acetic acid (2,4-D) at $4 \mathrm{lb} / \mathrm{acre}$ was applied in 10 gpa water with $0.1 \% \mathrm{X}-77$ in mid-July. Plot size was $12 \times 20 \mathrm{ft}$ with four replications. Basal area of iris was estimated the year of treatment and the following year to determine control. Herbage production was measured by clipping two $12-\mathrm{ft}^{2}$ subplots each year. Subplots for grass, grass-like, and forb yield were rotated yearly. Iris was harvested on adjacent areas of similar infestations since experience had shown that clipping, even for 1 year, can result in near eradication.

The first 2-year results indicated some problems associated with specics response and application date. Treatment with $4 \mathrm{lb} /$ acre 2,4-D gave excellent iris control but severely reduced the yield of forbs, especially dandelion and yarrow. In addition, recommendations for time of treatment ranged from bud stage to post bloom. Iris phenology is easily seen. However, stages do not occur as regularly on meadows in narrow canyons or at high elevations as on wide, valley meadows where previous work had been conducted. Cold air drainage and frost may almost eliminate expression of phenology. Therefore, timing of 2,4-D application by calendar date with some phenology would be more pertinent for high elevation meadows than would a phenologic stage which may not appear in some years or may be expressed by only a few plants.

A study was designed to resolve these two problems. Plots at two locations were treated in 1968 and 1969 with 2, 3, and $4 \mathrm{lb} /$ acre $2,4-\mathrm{D}$ in mid-June and early July. Plot size was $12 \mathrm{x}$ $12 \mathrm{ft}$ with three replications. Iris control was evaluated by tiller count. Yield of iris and forage species was determined for 2 years on the check and on plots treated with $3 \mathrm{lb} / \mathrm{acre}$ applied on the early date and $4 \mathrm{lb} /$ acre applied on the late date. Yield from these two treatments was representative of other treatments with excellent iris control. Forb yield was determined for 2 years on all treatments.

Water-table observation wells were dug to $20 \mathrm{ft}$, cased with perforated pipe, and back-filled with gravel.

Data were analyzed by analysis of variance; treatment means were compared by Duncan's Multiple Range Test. Probability of 0.05 was accepted as significant.

\section{Results and Discussion}

\section{Iris Control}

Excellent iris control (91 to $100 \%$ ) was obtained with 2, 3, or $4 \mathrm{lb} /$ acre $2,4-\mathrm{D}$ applied in mid-June or early July at Long Meadow, or with 3 or $4 \mathrm{lb} / \mathrm{acre}$ at Willow Creek. Iris phenology at time of treatment ranged from late vegetative to late bloom. The $2 \mathrm{lb} /$ acre treatment in early July at Willow Creek gave from 73 to $85 \%$ control. This treatment appears near the minimum concentration of 2,4-D needed for excellent iris control when applied after seed capsules start to form. Reduction in iris yield on successful treatments ranged from 398 to $1568 \mathrm{lb} /$ acre and averaged $925 \mathrm{lb} /$ acre.

\section{Production of Grass and Grass-Like Species}

Iris control in 1965 gave a significant yield increase of grass
Table 1. Production (lb/acre) of grass and grasslike species and precipitation (inches) for 5 years after treatment with $4 \mathrm{lb} / \mathrm{acre}$ 2,4-D at Long Meadow.

\begin{tabular}{lccc}
\hline & \multicolumn{2}{c}{ Production } & \\
\cline { 2 - 4 } Year & Treated & Check & Precipitation \\
\hline 1966 & $486 \mathrm{a}^{\mathrm{1}}$ & $212 \mathrm{~b}$ & 15.6 \\
1967 & $1782 \mathrm{a}$ & $829 \mathrm{~b}$ & 20.4 \\
1968 & $776 \mathrm{a}$ & $288 \mathrm{~b}$ & 18.7 \\
1969 & $1815 \mathrm{a}$ & $696 \mathrm{~b}$ & 25.8 \\
1970 & $2296 \mathrm{a}$ & $944 \mathrm{~b}$ & 19.9 \\
\hline
\end{tabular}

"Treatment means within year followed by different letters are significantly different at the 0.05 level as determined by Duncan's Multiple Range Test.

and grass-like species in subsequent years (Table 1). Yield increase over the check ranged from $274 \mathrm{lb} /$ acre in 1966 to $1352 \mathrm{lb} /$ acre in 1970 and averaged $837 \mathrm{lb} /$ acre or $143 \%$. Yield of iris on the check in these 2 years was 558 and $760 \mathrm{lb} /$ acre, respectively.

Yields in 1966 and 1968 were similar and were significantly less than in 1967, 1969, and 1970. Productivity was greatest in 1970. Low yields in 1966 and 1968 were attributed to adverse environmental conditions. Precipitation during the first 6 months of 1966 was only $40 \%$ of normal at the two closest stations. Other stations in the northern part of the state reported from 8 to $13 \%$ of normal through April. Precipitation was near normal in 1968; however, a killing frost occurred on June 29 and 30. Minimum temperatures at nearby stations were between 25 and $30^{\circ} \mathrm{F}$. With near-normal conditions, we would expect a greater yield the year after treatment than that obtained in 1966. Results in 1969 and 1970 at two locations support this speculation. Average yield increase the first and second years after treatment at Long Meadow was 1442 lb/acre (340\%) and $1433 \mathrm{lb} / \mathrm{acre}(153 \%)$, respectively. Firstyear increases on two other studies were $2364 \mathrm{lb} /$ acre $(360 \%)$ and $1135 \mathrm{lb} /$ acre $(111 \%)$. At Willow Creek the average yield increasc the first and second years after treatment was 728 lb/acre $(92 \%)$ and $652 \mathrm{lb} /$ acre $(106 \%)$, respectively.

The more productive species, slender wheatgrass (Agropyron trachycaulum) and Nevada bluegrass (Poa nevadensis), dominated the higher condition sites. Density of these species was greater at Long Meadow than at Willow Creek. Meadow barley (Hordeum brachyantherum), bluegrasses (Poa spp.), mat muhly (Muhlenbergia richardsonis), sedges (Carex spp.), and dense iris dominated the lower condition sites. At Long Meadow, Nevada bluegrass and meadow barley predominated near the stream channel. Slender wheatgrass predominated on sites away from the channel and at higher elevations in the meadow. The presence of squirreltail (Sitanion hystrix), Junegrass (Koeleria cristata), and Columbia needlegrass (Stipa columbiana) suggests that these sites are more zeric than sites adjacent to the stream. The differences in range condition and species composition explain the variations in total and species yield between and within location.

Iris control on sites dominated by Nevada bluegrass resulted in a yield response by this species the first year after treatment (558 lb/acre) compared to the check (106 lb/acre). During the following 4 years, yield varied between 160 and $502 \mathrm{lb} /$ acre on the check and between 520 and $1100 \mathrm{lb} /$ acre on treated plots. Slender wheatgrass responded slowly. Average yield the first 3 years after treatment was $16 \mathrm{lb} / \mathrm{acre}$. In 1969 and 1970 (Table 2) production had increased to 280 and $800 \mathrm{lb} / \mathrm{acrc}$, respectively. On sites away from the creek, slender wheatgrass responded the first year after treatment. Pretreatment yield in 
Table 2. Production (lb/acre) of grass, grasslike, and forb species on treated and check plots in 1970 at Long Meadow. Treatment (4 lb/ acre 2,4-D) was made in 1965.

\begin{tabular}{lrr}
\hline \hline & \multicolumn{2}{c}{ Production } \\
\cline { 2 - 3 } Species & Treated & Check \\
\hline Slender wheatgrass & $800 \mathrm{a}^{1}$ & $472 \mathrm{~b}$ \\
Nevada bluegrass & $960 \mathrm{a}$ & $448 \mathrm{~b}$ \\
Meadow barley & $352 \mathrm{a}$ & $16 \mathrm{~b}$ \\
Other grasses & $160 \mathrm{a}$ & $0 \mathrm{a}$ \\
Sedge & $24 \mathrm{a}$ & $8 \mathrm{a}$ \\
Iris & $152 \mathrm{a}$ & $760 \mathrm{~b}$ \\
Common dandelion & $32 \mathrm{a}$ & $40 \mathrm{a}$ \\
Western yarrow & $128 \mathrm{a}$ & $144 \mathrm{a}$ \\
Other forbs & $128 \mathrm{a}$ & $24 \mathrm{a}$ \\
Total herbage & $2736 \mathrm{a}$ & $1912 \mathrm{~b}$ \\
Grass and grasslike & $2296 \mathrm{a}$ & $944 \mathrm{~b}$ \\
Total forbs & $440 \mathrm{a}$ & $968 \mathrm{~b}$ \\
Sage grouse food plants & $160 \mathrm{a}$ & $184 \mathrm{a}$ \\
\hline
\end{tabular}

\begin{abstract}
Treatment means followed by the same letter are not significantly different at the 0.05 level as determined by Duncan's Multiple Range Test.
\end{abstract}

two studies averaged $88 \mathrm{lb} /$ acre. After 1 and 2 years, respectively, yield was 1450 and $1300 \mathrm{lb} / \mathrm{acre}$. Yield of Nevada bluegrass was $372 \mathrm{lb} /$ acre before treatment and 650 and 600 $\mathrm{lb} /$ acre 1 and 2 years after treatment. Species response at Willow Creek was similar although yield was about one-third to one-half that at Long Meadow.

A significant yield response was found in 10 to 11 measurements of treatment effects. No response in 1969 was attributed to a persistent watertable at $4.5 \mathrm{ft}$. In comparison, watertable depths from 1965 to 1971 ranged from 8 to $13 \mathrm{ft}$. A capillary fringe within the root zone of perennials would result from a shallow water table. Very high precipitation (33.2 inches) in 1968-69 contributed to the high water table by moisture percolating through the soil and by underground flow from the surrounding watershed. No yield response under conditions of high precipitation and high watertable suggests that the main effect of iris control is soil moisture conservation. A comparison of 1969 and 1970 yields revealed that lack of response in 1969 was due to increased check yield not to reduced treatment yield.

\section{Production of Forbs}

Oakleaf (1971) calculated that the sage grouse population of eight birds/acre at Long Meadow would consume about 10 $\mathrm{lb} / \mathrm{acre}$ of forbs during meadow occupancy. On this basis, total forb production the year after treatment (Table 3) was deficient or minimal except on plots treated with 2 or 3 $\mathrm{lb} / \mathrm{acre}$ in early July. Forb production the second year appeared adequate, except perhaps on plots treated with 4 $\mathrm{lb} /$ acre in early July. Yield of sage grouse food plants 3, 4, and 5 years after treatment was 96, 200, and $160 \mathrm{lb} / \mathrm{acre}$, respectively with 20,24 , and $32 \mathrm{lb} /$ acre of dandelion. Two factors, other than total forb yield, need consideration. Dandelion is a preferred species (82\% of meadow forbs consumed) compared to yarrow (7\%) (Savage, 1968). A forb component of least preferred species will not satisfy sage grouse needs. The year after treatment, dandelion production (Table 3) was generally deficient. Therefore, even though total forb yield approached $10 \mathrm{lb} / \mathrm{acre}$, forb composition would not be considered adequate for good sage grouse habitat. Data on total forb yield and species yield can also be misleading because sage grouse do not consume the entire plant but remove the more succulent portions. We do not know the total production necessary to supply the required intake of succulent parts.

\section{Conclusions and Management}

Iris-infested mountain meadows can be improved for livestock and wildlife. Excellent iris control was obtained with 2,4-D at $2 \mathrm{lb} /$ acre applied from mid-June to early July when iris was in the late vegetative to late bloom stage. Treatment after seed capsules start to form will require more herbicide for similar control, or acceptance of less uniform or reduced control.

With near-normal environmental conditions, a large yield response by grass and grass-like species can be expected the first and succeeding years after treatment. The total and species response depend on meadow condition and species composition at time of treatment.

Yield of important sage grouse food plants, dandelion and yarrow, was severely reduced the first year after treatment, and production of the preferred species, dandelion, was not adequate for the existing sage grouse populations. Total forb production and the dandelion component appeared adequate for sage grouse the second and subsequent years after treatment.

Variability in range condition, species composition, and water table results in degrees of iris infestation. In dense iris, forbs are almost eliminated, and suppressed perennial grasses are found only in iris clumps. These dense stands might reasonably be treated first to increase grass and forb production. On most meadows, spot treatment can be done with a backpack sprayer. With such equipment the applicator has more control over nontarget areas such as good forb stands and streams. Untreated areas will supply some forbs for sage grouse while production on treated arca is reduced for 1 year. In an intensive improvement program, different portions of the meadow can be treated periodically until iris is no longer a problem.

Vegetation management after iris control is important. Perennial grass in iris clumps is in low vigor. Therefore, the large response in vigor and seed production will occur the year after treatment. Livestock use should be deferred until after seed-ripe to disperse and plant grass and forb seed. This should be followed by deferment necessary for seedling establishment before normal use.

Eckert et al. (1973), suggested that large seeded meadows be fenced and managed for livestock and wildlife and that

Table 3. Forb production (lb/acre) the year of treatment (1969) and for 2 years after treatment at Long Meadow.

\begin{tabular}{cccccccc}
\hline \hline \multirow{2}{*}{$\begin{array}{c}\text { Plot and } \\
\text { date }\end{array}$} & \multicolumn{3}{c}{ Common dandelion } & & \multicolumn{3}{c}{ Western yarrow } \\
\cline { 2 - 4 } \cline { 6 - 7 } \cline { 6 - 7 } & 1969 & 1970 & 1971 & & 1969 & 1970 & 1971 \\
\hline Check & 160 & $272 \mathrm{a}^{1}$ & $60 \mathrm{a}$ & & 248 & $264 \mathrm{a}$ & $156 \mathrm{a}$ \\
$2 \mathrm{~A}^{2}$ & & $5 \mathrm{~b}$ & $41 \mathrm{ab}$ & & $5 \mathrm{c}$ & $52 \mathrm{ab}$ \\
$2 \mathrm{~B}^{3}$ & & $16 \mathrm{~b}$ & $35 \mathrm{ab}$ & & $136 \mathrm{~b}$ & $62 \mathrm{ab}$ \\
$3 \mathrm{~A}$ & & $1 \mathrm{~b}$ & $25 \mathrm{ab}$ & & $2 \mathrm{c}$ & $18 \mathrm{~b}$ \\
$3 \mathrm{~B}$ & & $6 \mathrm{~b}$ & $20 \mathrm{ab}$ & & $21 \mathrm{c}$ & $11 \mathrm{~b}$ \\
$4 \mathrm{~A}$ & & $5 \mathrm{~b}$ & $22 \mathrm{ab}$ & & $5 \mathrm{c}$ & $5 \mathrm{~b}$ \\
$4 \mathrm{~B}$ & & $2 \mathrm{~b}$ & $10 \mathrm{~b}$ & & $2 \mathrm{c}$ & $3 \mathrm{~b}$ \\
\hline
\end{tabular}

${ }^{1}$ Treatment means within year followed by the same letter are not significantly different at the 0.05 level as determined by Duncan's Multiple Range Test.

${ }^{2} A$ date, 6/17-Dandelion phenology: second or third bloom, achenes from earlier flowers mostly dehised. Yarrow phenology: leaf to early flower bud.

${ }^{3} B$ date, 7/8-Dandelion phenology: post bloom, seed mostly dehised. Yarrow phenology: late bud to early flower. 
small meadows be managed exclusively for wildlife with livestock use designed to maintain quality wildlife habitat. Meadows improved by iris control, and possibly all meadows, should be managed for the same objectives. However, the kind of management needed to benefit livestock, wildlife, and the site is unknown.

\section{Literature Cited}

Cords, H. P. 1960. Control of wild iris. Univ. of Nev. Agr. Exp. Sta. Bull. $199.4 \mathrm{p}$

Cords, H. P. (Ed.). 1972. Nevada weed control recommendations. Univ. of Nev. College of Agr. C-117.41 p.

Dayton, William A. 1960. Notes on western range forbs: Equsitaceae through Fumariceae. U. S. Dept. Agr., Agr. Handbook No. 161. 254 p.

Eckert, Richard E., Jr., Allen D. Bruner, Gerard J. Klomp, and Fredrick
F. Peterson. 1973. Mountain meadow improvement through seeding. J. Range Manage. 26:200-203.

Oakleaf, Robert J. 1971. The relationship of sage grouse to upland meadows in Nevada. Nev. Dep. of Fish and Game. Job Final Rep., Project W-48-2, R-Study VII. 64 p.

Pryor, Murry R., and R. E. Talbert. 1958. Iris missouriensis: A serious weed pest. The Bulletin, Dep. of Agr., State of Calif., Bureau of Rodent and Weed Control and Seed Inspection XLVII. 4 p.

Robocker, W. C. 1966. Wild iris. In Chemical Control of Range Weeds. U. S. Dep. of Agr., and U. S. Dep. of the Interior. 39 p.

Savage, David E. 1968. The relationship of sage grouse to upland meadows in Nevada. Unpublished M.S. Thesis, Univ. of Nevada, Reno, Nevada. 127 p.

Savage, David E., Glen C. Christensen, and Richard E. Eckert. 1969. The relationship of sage grouse to upland meadows in Nevada. 6th Biennial Western States Sage Grouse Workshop. Rock Springs, Wyoming, Sept. 3-5. p. 134-141.

U. S. Dep. of Commerce. 1965-1971. Climatological Data for Nevada. 